Rodrigo Telles Pires Hallak

\title{
Análise da Governança Corporativa como Determinante das Despesas de Auditoria e Consultoria no Brasil
}

Dissertação apresentada ao Programa de PósGraduação em Administração de Empresas da PUCRio como requisito parcial para obtenção do título de Mestre em Administração de Empresas.

Orientador: Prof. André Luiz Carvalhal da Silva

Rio de Janeiro,

Agosto de 2011 


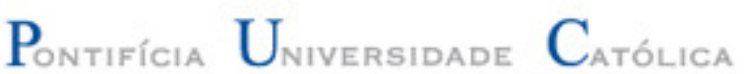

Rodrigo Telles Pires Hallak

\section{Análise da Governança Corporativa como Determinante das Despesas de Auditoria e Consultoria no Brasil}

Dissertação apresentada como requisito parcial para obtenção do grau de Mestre pelo Programa de PósGraduação em Administração de Empresas da PUC-Rio. Aprovada pela Comissão Examinadora abaixo assinada.

Prof. André Luiz Carvalhal da Silva

Orientador

Departamento de Administração, PUC-Rio

Prof. Leonardo Lima Gomes Departamento de Administração, PUC-Rio

Prof. Marcelo Verdini Maia

Departamento de Administração, PUC-Rio

Prof. Ricardo Pereira Câmara Leal

UFRJ

Prof $^{a}$. Mônica Herz

Vice-Decana de Pós-Graduação do CCS

Rio de Janeiro, 05 de agosto de 2011 
Todos os direitos reservados. É proibida a reprodução total ou parcial do trabalho sem autorização da universidade, do autor e do orientador.

\section{Rodrigo Telles Pires Hallak}

Graduou-se em Administração pela Universidade Federal do Rio de Janeiro (UFRJ) em 2008. Atua como administrador no Banco Nacional de Desenvolvimento Econômico e Social (BNDES).

Ficha Catalográfica

Hallak, Rodrigo Telles Pires

Análise da governança corporativa como determinante das despesas de auditoria e consultoria no Brasil / Rodrigo Telles Pires Hallak ; orientador: André Luiz Carvalhal da Silva. -2011.

$43 \mathrm{f.} ; 30 \mathrm{~cm}$

Dissertação (mestrado)-Pontifícia Universidade Católica do Rio de Janeiro, Departamento de Administração, 2011.

Inclui bibliografia

1. Administração - Teses. 2. Despesas com auditoria. 3. Despesas com consultoria. 4. Governança corporativa. I. Silva, André Luiz Carvalhal da. II. Pontifícia Universidade Católica do Rio de Janeiro. Departamento de Administração. III. Título. 


\section{Agradecimentos}

À minha família, pelo amor sincero e apoio contínuo e por todos os ensinamentos passados.

Aos meus amigos, presentes nos momentos de alegria e tristeza.

À PUC-Rio, pelos auxílios concedidos, sem os quais este trabalho não poderia ter sido realizado.

Aos meus professores, por todos os conhecimentos compartilhados. 


\section{Resumo}

Hallak, Rodrigo Telles Pires; Silva, André Luiz Carvalhal da. Análise da Governança Corporativa como Determinante das Despesas de Auditoria e Consultoria no Brasil. Rio de Janeiro, 2011. 43p. Dissertação de Mestrado - Departamento de Administração, Pontifícia Universidade Católica do Rio de Janeiro.

O objetivo dessa pesquisa é identificar fatores que influenciem na determinação de gastos com auditoria e consultoria por parte das empresas abertas no mercado brasileiro. A principal motivação do presente estudo foi a falta de pesquisas sobre gastos com auditoria e consultoria no Brasil, enquanto que esse assunto já vem sendo explorado há anos em outros países. Cabe ressaltar que essa escassez de dados no Brasil é devido ao fato de que, só a partir de 2009, tornou-se obrigatória a divulgação das quantias despendidas com serviços de auditoria e consultoria de forma separada. A divulgação desses dados possibilita a análise dos determinantes dos valores pagos pelas empresas por tais serviços. Os resultados indicam que as despesas de auditoria estão positivamente relacionadas com o tamanho da companhia, price-to-book, qualidade da governança corporativa e com o fato de a empresa de auditoria ser uma Big Four e negativamente relacionadas com a alavancagem da firma. Já quanto aos gastos de consultoria, existe uma relação positiva com o tamanho da empresa e negativa com a presença estatal no controle da companhia contratante dos serviços.

\section{Palavras-chave}

Despesas com auditoria; despesas com consultoria; governança corporativa. 


\section{Abstract}

Hallak, Rodrigo Telles Pires; Silva, André Luiz Carvalhal da (Advisor). Analysis of Corporate Governance as Determinant of Audit and NonAudit Fees in Brazil. Rio de Janeiro, 2011. 43p. Msc. Dissertation Departamento de Administração, Pontifícia Universidade Católica do Rio de Janeiro.

The objective of the present study is to identify factors that have an impact on the determination of audit and non-audit fees paid by Brazilian publicly traded companies. The main motivation of the present study was the lack of research in Brazil about audit fees and non-audit fees, while the subject has been discussed for many years in other countries. It is important to highlight that this shortage of research is due to the fact that, only in 2009 , it become mandatory the disclosure of money spent in each type of service. Such transparency allows the analysis of the determinants of the values paid by enterprises for these services. The results indicate that the audit fees are positively related to firm size, price-to-book, corporate governance quality and the fact that the auditor is a Big Four, and negatively related to leverage. In terms of non-audit fees, there is a positive relation with firm size and they are lower in State-owned firms.

\section{Keywords}

Audit expenses; non-audit expenses; corporate governance. 


\section{Sumário}

1. Introdução 9

2. Revisão bibliográfica $\quad 12$

2.1. Governança corporativa e auditoria externa 12

$\begin{array}{ll}\text { 2.2. Gastos com serviços de auditoria e consultoria } & 16\end{array}$

3. Dados e metodologia 22

4. Análise dos resultados 25

5. Conclusões 38

6. Referências bibliográficas 41 


\section{Lista de tabelas}

Tabela 1 - Estatística descritiva das variáveis $\quad 25$

Tabela 2 - Despesas de auditoria e características das empresas 27

Tabela 3 - Despesas de consultoria e características das empresas 28

Tabela 4 - Despesas de auditoria e consultoria e governança corporativa $\quad 30$

Tabela 5 - Regressões com despesas de auditoria 31

Tabela 6 - Regressões com despesas de auditoria relativa 34

Tabela 7 - Regressões com despesas de consultoria 35

Tabela 8 - Regressões com despesas de consultoria relativa 37 